Debreceni Jogi Múhely 2020. (XVII.) 3-4.

Debreceni Egyetem, Állam- és Jogtudományi Kar, Debrecen

(University of Debrecen, Faculty of Law, Debrecen)

DOI 10.24169/DJM/2020/3-4/11

Tucsek Máté

joghallgató

Szegedi Tudományegyetem, Allam-és Jogtudományi Kar, Civilisztikai Tudományok Intézete

\title{
A JOGCÍMES ELBIRTOKLÁS KÉRDÉSEI
}

Debreceni Jogi Múhely, 2021. évi (XVIII. évfolyam) 1-2. szám (2021. szeptember 1.)

DOI 10.24169/DJM/2021/1-2/7

Abstract: In this paper I am willing to introduce different aspects of the new institution of the Hungarian civil law, the so-called prescription by title. This young way of acquiring property was a novelty in the field of law and jurisprudence, and a novelty for entities as well. The law of property contains the most important and fundamental rules of private law, this is the reason why it is always ultimately important that the legislator and the exact purpose of the legislation has to be as clearly defined as possible, since this is what ensures the security of property transactions and guarantees the freedom and protection of one of the most ancient social institutions, property. By its unique nature, prescription has always been the subject of legal disputes, thus the arguments above are cumulative.

The aim of this paper is to present the regulation of prescription by title, its dogmatic features, draw parallels with its ancestor in Hungarian legal history and an unusual foreign example, examine some relevant aspects of judicial practice and finally attempt to compose a possible alternative regulatory technique.

Keywords: right in rem, prescription, legal title, privileged, civil law, 5:45. \$

Absztrakt: Jelen dolgozatban a Polgári Törvénykönyben felvázolt új dologi jogintézmény, a jogcímes elbirtoklás egyes aspektusainak bemutatására szándékozom. Ezen fiatal tulajdonszerzési mód a jogalkalmazás és a jogtudomány számára merôben szokatlannak hatott, és a jogalanyok vonatkozásában is novumnak számít. A dologi jog a magánjog legfontosabb, leglényegeseb szabályait tartalmazza, ezért mindig égetôen fontos, hogy a jogalkotó, továbbá a jogszabály egzakt célját sikerüljön feltárni a lehető legpontosabb módon, hiszen ez szolgálja a vagyoni forgalom biztonságát, és ez garantálja az egyik legősibb társadalmi intézmény, a tulajdon szabadságát és védelmét. Az elbirtoklás sajátos természeténél fogva mindig jogviták kereszttüzében állt, így a fenti szempontok esetében halmozottan érvényesülnek.

Jelen dolgozat célja, hogy bemutassa a jogcímes elbirtoklás szabályozását, dogmatikai sajátosságait, magyar jogtörténeti előzményével, valamint egy szokatlan külföldi példával párhuzamot vonjon, a bírói gyakorlat egyes releváns mozzanatait megvizsgálja, és kísérletet tegyen egy alternatív szabályozási technika felvázolására.

Kulcsszavak: dologi jog, elbirtoklás, jogcímes, privilegizált, magánjog, 5:45. \

\section{Bevezető gondolatok}

„Ha sérelem éri akár csak egyetlen ember tulajdonjogát, azzal sérül mindenki tulajdonjoga.” (Napóleon, 2015, p. 156.) Az elbirtoklás a magánjog talán legmarkánsabb intézményeinek egyike. Napjaink embere fokozódó intenzitással viseltet vagyoni ügyei iránt. A tulajdon jelentősége vitathatatlanul nő, ezzel együtt nő a mindenkori jogalkotó szerepe: A tulajdon megszerzése és védelme szabályainak egyszerre kell kellően rugalmasnak és szilárdnak lennie ahhoz, hogy a tulajdonosok érdeke ne sérüljön, de a piaci élet, 
Debreceni Jogi Múhely 2020. (XVII.) 3-4.

Debreceni Egyetem, Állam- és Jogtudományi Kar, Debrecen

(University of Debrecen, Faculty of Law, Debrecen)

DOI 10.24169/DJM/2020/3-4/11

a környezeti változások hatásai se kerülhessék el a tulajdonjog tárgyait.

A polgári jogban az időmúlás kérdésében drámai változás állt be: nem elsősorban az időtartamra vonatkoznak, hanem az ennek folytán beálló jogkövetkezmények feltételeire (Zimmerman, 2007, pp. 806-809.). Az elbirtoklás kérdéskörében - a magyar jogban legalábbis - ilyen éles szemléletváltás nem következett be, megjelent azonban egy régi - új intézmény: a jogcímes elbirtoklás. Az intézmény olyannyira fiatal, hogy tárgyában számottevő, egységes szakirodalmi szöveg nem született, a bírói gyakorlatban pedig aligha beszélhetünk egységes alkalmazási struktúráról, jóllehet a jogcímes elbirtoklás kérdésében született határozatok száma is igen csekély. ${ }^{1}$

\section{Elvi előkérdések - A jogcímes elbirtoklás szabályozása, dogmatikai sajátosságai}

Az elbirtoklás a tulajdon megszerzésének fogalmi körén belül értelmezendő, így e körben a hozzá kapcsolódó jogszabályok és jogi dokumentumok tulajdont érintő rendelkezései relevánsak.

A második világháborút követően kritikussá vált a tulajdon védelmének egyetemes okmányokban való védelme, hiszen a globalizációval a magántulajdon érzékenysége is egyre nőtt. (Lamm, 2018, p. 713). Például, az Európa Tanács legjelentősebb alapjogi dokumentuma, az Emberi Jogok Európai Egyezménye 2 (1950) 1952-es első kiegészítő jegyzőkönyve 1. cikke iktatta be a tulajdon békés élvezetéhez való jogot. Az Európai Unió Bírósága számos ügyben foglalkozott a tulajdonhoz való alkotmányos joggal, elismerve annak jogosultságát a Közösségi jogalkalmazás szintjén is. Az Európai Unió Alapjogi Chartája meglehetős részletességgel foglalkozik II. fejezetének 17. cikkében a tulajdonhoz való joggal (Tóth, 2018, p. 225)

Magyarország Alaptörvénye a Szabadság és Felelősség cím alatt, a XIII. cikkben szabályozza a tulajdonhoz kapcsolódó alapjogot, kimondja, hogy „Mindenkinek joga van a tulajdonhoz és az örökléshez. A tulajdon társadalmi felelősséggel jár." Természetesen az alkotmányjog eszközei a tulajdonba való állami beavatkozással szemben védenek, a tulajdonjog legátfogóbb védelmére, tartalmának megállapítására, szabályainak pontos kijelölésére elsősorban a polgári jog hivatott (Tóth, 2018, p. 217).

Ennek megfelelően a Polgári Törvénykönyv feladata a tulajdonvédelem horizontális, magánszemélyek közötti biztosítása. A Ptk. Ötödik Könyve tartalmazza a legfontosabb vonatkozó dologi jogi szabályokat, IV. Címe alatt taglalja a tulajdon tartalmát V. Címe alatt találhatók a Tulajdonjog megszerzésére vonatkozó, a XII. Fejezetben pedig az elbirtoklásra vonatkozó rendelkezések. A jogcímes elbirtokláshoz kapcsolódó jogalkotói megoldás az általános - különös szabályok viszonyrendszerét követi, a Ptk. 5:44. \az (általános) elbirtoklás feltételeit és ,jogi hatásá”-t, a Ptk. 5:45 \ ehhez képest a speciális esetet, a jogcímes elbirtoklás szabályait fekteti le.

„Ptk. 5:45. $\int A z$ z elbirtoklás öt év elteltével këvetkerịk be, ha a birtokos az ingatlan birtokát a tulajdonostól olyan irásbeli szerrớdéssel szeręte, amelynek alapján a tulajdonjogának ingatlan-nyilvántartási bejegyzését këvetelhetné, ha a sžerzớdés az ehbez megkivánt alakszerüségi követelményeknek megfelelne, és a birtokos az ellenszolgáltatást teljesitette."

A Polgári Törvénykönyvrôl szóló 2013. évi V. törvény hatálybalépésével összefüggő átmeneti és felhatalmazó rendelkezésekről szóló 2013. évi CLXXX törvény (Ptké.) a 47. \-ában füz egy fontos átmeneti szabályt a Ptk. 5:45 \-ához. Eszerint a Ptk. jogcímes elbirtoklásra vonatkozó rendelkezéseit a folyamatban lévő elbirtoklásra is alkalmazni rendeli azzal, hogy amennyiben a jogcímes elbirtokláshoz szükséges idő már eltelt, vagy abból kevesebb, mint egy év van hátra, a birtokos a tulajdonát a Ptk. hatálybalépését követô egy év elteltével szerzi meg. A bírói gyakorlat egyes elemeiben kirajzolódni látszik az, hogy ha az rPtk. szerinti elbirtokláshoz egyébként szükséges idő (15 év) már eltelt, a peres felek tulajdoni igényüket jogcímes elbirtoklásra nem alapíthatják. ${ }^{3}$

\footnotetext{
1 A Bírósági Határozatok Gyújteménye szerint összesen 28 határozat született a jogcímes elbirtoklás kapcsán. Letöltve: https:/ / eakta.birosag.hu/anonimizalt-hatarozatok. (Utolsó letöltés: 2020. december 4.)

2 Magyarországon kihirdette: 1993. évi XXXI. tv.

3 (BH 2016.340.)
} 
Debreceni Jogi Múhely 2020. (XVII.) 3-4.

Debreceni Egyetem, Állam- és Jogtudományi Kar, Debrecen

(University of Debrecen, Faculty of Law, Debrecen)

DOI 10.24169/DJM/2020/3-4/11

A jogcímes elbirtoklás az elbirtoklás privilegizált esete. A törvény ingatlantulajdon elbirtoklása körében rendel rövidebb, 5 éves elbirtoklási időt, az elbirtokló számára - azáltalános 15 évhez képest - lényegesen kedvezőbb helyzetet teremtve. Ahhoz, hogy ez a kedvezmény fennforoghasson, 4 konjunktív feltétel teljesülése szükséges: 1) az elbirtoklás törvényi feltételei fennállnak, 2) 5 évig, de 3) a szerződésből származó tulajdonjogot alaki hiba miatt nem lehet az ingatlan-nyilvántartásba bejegyezni, és 4) a birtokos az ellenszolgáltatást teljesítette. Az alábbiakban ezen konjunktív feltételek részletes dogmatikai vizsgálatáról lesz szó.

Az elbirtoklás intézménye mögött össztársadalmi érték fekszik: a személyek azáltal, hogy az általuk huzamosabb ideig birtokolt, hasznosított idegen javak felett jogcímüket a tulajdon megszerzésével biztosíthatják, érdekeltté válnak a gazdálkodás minél hatékonyabb folytatásában. Ezzel párhuzamos értékelés alá kell vetni a tulajdonos nemtörődömségét, azaz, hogy a tulajdonában álló dolgok (jogi) sorsa számára érdektelen. Ha az elbirtoklás szabályai hiányoznának, a bizonytalan társadalmi viszonyok korlátlan ideig fennállnának, és ez a helyzet az áruforgalom vészes bizonytalanságához vezetne (Gárdos, 2009, pp. 402-403). Az 1959-es Ptk. indokolása kimondottan a tulajdonos hanyagságára, illetve az idő múlására helyezte a hangsúlyt, mely azonban anakronizmus, hiszen a magyar magánjog a tulajdoni igényeket alapvetően elévülhetetlenné teszi, azaz a tulajdonos puszta tétlensége még nem okozza azok megszűnését, de problémás a passzivitás értékelése olyan ingók vonatkozásában is, amelyek hollétéről a tulajdonosnak nincs tudomása. (Pusztahelyi, 2014, p. 184).

Hasonlóan az rPtk-hoz, a hatályos magyar szabályozás továbbra sem követeli meg a jóhiszemúséget, megelégszik a sajátjakénti birtoklással. A sajátjakénti birtoklás meghatározásával a Ptk. adós marad, a tudomány és a bírói gyakorlat azonban többé-kevésbé következetes a fogalom használata kapcsán, objektív elemként a külvilág felé tulajdonosként való megnyilvánulást, szubjektív elemként azt a tudati elemet határozza meg, ami - alapos okot feltételezve - a birtoklás véglegesnek tekintésére vonatkozik. ${ }^{4}$ Előbbire példa lehet a hatóságok elôtti önálló fellépés, a más személyek előtt tett kijelentés. ${ }^{5}$

A Ptk. a szakadatlan birtoklás fogalmát sem határozza meg, ám az elbirtoklás megszakadásának eseteit a Ptk. 5: 49. \ felsorolja. A tulajdonosi jog gyakorlása kapcsán megjegyzendő, hogy az nem egyenértékú a rendelkezés jogosítványával, az mindennemú, a tulajdonosi részjogosítványok gyakorlásához kapcsolódó joggyakorlás lehet.

A Ptk. az ingatlantulajdon elbirtoklásához generális szabályként 15 éves elbirtoklási idôt füz, mely egyensúlyt kíván teremteni a tulajdonosi jogok gyakorlásához füződő érdek, és a társadalmi bizonytalan helyzet mielőbbi felszámolása között (Vékás, 2008, p. 632). Az 5 éves elbirtoklási idő ehhez képest lényegesen kedvezőbb helyzetet teremt a birtokosnak, ami logikusan következik abból, hogy a tulajdonos (ti. a szerződő fél) saját akaratelhatározásából engedte át az ingatlan birtokát, és ezért ellenszolgáltatást is kapott. Szembetűnő, hogy az elévülés általános határideje is 5 év [Ptk. 6:22. \(1) bekezdés], nem véletlenül. A bejegyzési engedély kiadása iránti követelés ugyanis kötelmi jellegú, és ezt az elvet követi a bírói gyakorlat is a Legfelsőbb Bíróság nyomán (EBH2004. 1136.). Így ezen igény esedékessé válását követő 5 év elteltével a birtokos kötelmi alapon már nem, kizárólag dologi jogszerzésre hivatkozva kérheti a bíróságtól tulajdonjogának megállapítását (Szőke, 2002, pp. 3-18).

A jogcímes elbirtoklás intézménye szükségképpen hibás tulajdonátruházást feltételez. A civilisztikai dogmatika hagyományosan két csoportra bontja a tulajdonszerzési módokat: eredeti és származékos szerzésmódokra (Tolnai-Fónyiné Kazareczki, 2020).

Az ingatlan tulajdonjogának átruházása két eltérő mozzanatból tevődik össze: a jogcím, azaz az a jogi cél, amelynek érdekében a tulajdonjog megszerzése végbemegy, és a szerzésmód, az átruházó dologi jogügylet. Ezzel szemben a kauzális vagy konvencionális magánjogok esetében a tulajdon átszállása a szerződéskötéssel végbemegy (Boóc, 2009, p. 119). Ingatlanok esetén az elbirtoklás vizsgálata

\footnotetext{
${ }^{4}$ Az rPtk. miniszteri indokolása szerint „sajátjaként nemcsak az birtokol, aki úgy véli, hogy a sajátját birtokolja, hanem az is, aki tudja ugyan, hogy a dolog másé, de véglegesnek tekinti a maga birtoklását. Ez nem pusztán szubjektív megítélés kérdése, mert hiszen a birtoklás jogcíme (pl. földhasználati juttatás, bérlet, zálogjog, letét) az ilyen jogviszony megszűntéig a birtokos szándékától függetlenül gátolja az elbirtoklás megkezdését.” 5 (BH 1975. 509.).
} 
Debreceni Jogi Múhely 2020. (XVII.) 3-4.

Debreceni Egyetem, Állam- és Jogtudományi Kar, Debrecen

(University of Debrecen, Faculty of Law, Debrecen)

DOI 10.24169/DJM/2020/3-4/11

szempontjából megemlítendő egy másik csoportosítási szempont, nevezetesen az, hogy az ingatlannyilvántartásba történő bejegyzés keletkezteti-e a tulajdont, vagy az alapul szolgáló jogi tény. Előbbi az átruházás, utóbbi pedig az ex lege tulajdonszerzés, ahol a beálló jogi tény mellett továbbra is szükséges a tulajdon ingatlan-nyilvántartásba történő bejegyzés, deklaratív hatállyal.

A Ptk. az 5:167. §-ban akként rendelkezik, hogy az ingatlan-nyilvántartásba jog, vagy jogilag jelentős tény bejegyzésére, feljegyzésére, az adatok átvezetésére kizárólag jogszabályban meghatározott okirat, továbbá bírósági, vagy hatósági határozat alapján kerülhet sor, a Ptk. 6:215 (2) bekezdése pedig rögzíti, hogy amennyiben a szerződés tárgya ingatlan, az adásvételi szerződést írásba kell foglalni.

Az Inytv. ${ }^{6} 29$. \-a taglalja részletezően, hogy ennek az okiratnak tartalmilag milyen kritériumoknak kell megfelelnie. Mivel a Ptk. 5:45. \az írásbeliség megléte mellett alakszerúségi követelményekre vonatkozik így szükségképpen olyan hibákról lehet szó, melyek a dokumentum okirati jellegéhez kapcsolódnak.7 Ezeket a kritériumokat a jogalkotó az Inytv. 29-38.\$-ban sorolja fel. Tartalmaznia kell például az ügyfél természetes személyazonosító adatait, lakcímét és személyi azonosítóját, az érintett ingatlan pontos megjelölését (település neve, helyrajzi szám) és a bejegyzéssel érintett tulajdoni hányadot, a jog vagy tény pontos megjelölését, a jogváltozás jogcímét stb.).

Az ellenszolgáltatás teljesítéséből logikailag levezethető, hogy kizárólag visszterhes jogügyletek folytán lehetséges a jogcímes elbirtoklás. Itt szükséges leszögezni, hogy mindez nem alkalmazható azokban az esetekben, ahol a birtokos - az elbirtoklást kizáró -, a dolog ideiglenes használatára jogosító jogcím folytán használja az ingatlant. ${ }^{8}$

A fentieket szintetizálva megállapítandó, hogy a jogalkotó a jogcímes elbirtoklás kapcsán különös helyzetet értékelt az elbirtokló javára: egy eredetileg származékos tulajdonszerzésnek induló, annak kritériumait részben beteljesítő, azonban hibája miatt a traditio mozzanatára nem képes szerződéses helyzetet az eredeti, ex lege szerzések között kívánt orvosolni. ${ }^{9}$

Egészen másban látta azonban a jogcímes elbirtoklás lényegét a Kúria egy elôtte zajló ügyben, ahol hibásan- az írásbeliség elmaradásában ${ }^{10}$ találta meg a privilegizált eset alkalmazhatóágát. ${ }^{11}$

\section{Megjegyzés a magyar jogtörténeti előzményekről.}

A magyar magánjog történetében már korábban megjelent ez az intézményi koncepció: Rámutat erre a Kézikönyv az Új Magyar Polgári Törvénykönyvhöz (Gárdos, 2009), megemlíti ugyanis, hogy az 1928-as Mtj. 550. \$-a (és 604. \-a) is rövidített elbirtoklási idôt tartalmaztak.

Már a Tripartitum ${ }^{12}$ is rendelkezett az elbirtoklásról, megállapítva azt a különösen hosszú elbirtoklási időt (32 év), ami a magyar magánjog történetének általános időtartama (Homoki Nagy, 2001, pp. 48-49), igaz, ekkor még a jogcímnek nem volt különösebb szerepe, és ez gyakorlatilag változatlanul érvényesült a

\footnotetext{
6 1997. évi CXLI. törvény az ingatlan-nyilvántartásról.

7 Ld: XXV PED, II. pontja: „Az írásba foglalt szerződés érvényességének nem feltétele, hogy a felek a megállapodásukat közokiratba vagy teljes bizonyító erejű magánokiratba foglalják, kivéve ha ezt külön jogszabály írja elő."

${ }^{8}$ Lásd: BH. 2016. 522.

9 A jogcímes elbirtoklás attól még eredeti szerzésmód marad, hogy kritériuma egy ideális esetben származékos szerzésmódot keletkeztető elem.

${ }^{10}$ VÉKÁs LAJOS: Szerzódések joga. ELTE Eötvös Kiadó, Budapest, 2019. 123-124. oldalán világosan rámutat erre a problémára: ugyan a kötelmi elkötelező jogügylet alaki érvényességéhez csak írásbeliséget követel meg a törvény (Ptk. 6:6 §), azonban a forgalom biztonsága szempontjából a dologi rendelkező ügylet, a bejegyzési engedély (clausula intabulandi) érvényességi kelléke az egyszerű írásbeli formán túl a teljes bizonyító erejű, ügyvédi (jogtanácsosi) ellenjegyzéssel ellátott okiratba vagy közokiratba foglalás.

${ }^{11} \mathrm{BH}$ 2018. 322.

12 HK. I. 78. czim: „1. \ Tudnunk kell tehát, hogy az elévülés annak az időnek eltelése, melyet a törvény a fekvő jószágok jogszerű megtartására és visszaszerzésére nézve megállapított. 2. \ Mely az eladott, elfoglalt, vagy bármiképen elidegenitett királyi fekvő jószágokra és birtokjogokra nézve száz, az egyháziakra nézve negyven, a nemesiekre nézve harminczkét, a polgáriakat illetőleg pedig tizenkét év lefolyásával telik le.”
} 
Debreceni Jogi Múhely 2020. (XVII.) 3-4.

Debreceni Egyetem, Állam- és Jogtudományi Kar, Debrecen

(University of Debrecen, Faculty of Law, Debrecen)

DOI 10.24169/DJM/2020/3-4/11

magyar magánjog teljes történetében.

Az 1928-as Magyar magánjogi törvénykönyv javaslata (Mezey, 2007. p. 172) (Mtj) ezzel szemben szakítani kívánt az elbirtoklás homogenizált megközelítésének sivárságával. Az Mtj 550. \-a tartalmában szinte azonos a Ptk. 5:45. \$- ával, ugyanis így szól: „Az elbirtoklás már három év elteltével bekövetkerịk, ba a birtokos az ingatlan birtokát a tulajdonostól vagy jogutódától oly szerzódéssel szeręte, amelynek alapján a tulajdon feltétlen átrubázását követelheti vagy legalább követelhetné, ha a szerzódés az érvényességébez. megkivánt alaknak. megfelelne és egyszersmind a tulajdonért esetleg járó ellenszolgáltatást teljesitette vagy teljesitit." Érdekes az 1928-as Mtj szóhasználata, hiszen a kijelentő és feltételes mód, valamint a múlt és jelen idejú igék egymást követik a törvényszövegben, ezen jogalkotói megfontolásból pedig a szabály mögött meghúzódó, lényegesen különböző esetekre lehet következtetni. Egyfelől megszerezhető lett volna az ingatlan tulajdonjoga abban az esetben, ha a szerződés alakilag és tartalmilag egyaránt megfelelő, és akkor is, ha formailag érvénytelen (Pusztahelyi, 2014, p. 192), azonban ezen hiba hiányában a szerződés érvényes lenne. Az ellenszolgáltatás vonatkozásában nem feltétlenül szükséges annak megtörténtét igazolni, elég, azt az igényérvényesítéskor teljesíteni, továbbá a „tulajdonért esetleg járó ellenszolgáltatást” fordulat arra enged következtetni, hogy a jogalkotói szándék - szemben a maival - nem csak a visszterhes, hanem az ingyenes (például ajándékozási) szerződések esetében is alkalmazni rendelte az elbirtoklás ezen kedvezményes esetét.

Az 1959. évi Ptk. 121. \-a szabályozta az elbirtoklás kérdését, és merőben korszerű megfontolásból - t.i. a 32 éves idô a kezdetleges áruforgalomnak megfelelő, a tulajdonos magatartásának értékeléséhez ez már nem szükséges -13 10 évre csökkentette az elbirtoklási időt ingatlanok esetében is, majd a Polgári törvénykönyvről szóló 1959. évi IV. törvényben szabályozott elbirtoklási határidő módosításáról szóló 2001. évi XIX. törvénnyel a jogalkotó ingatlanok esetében 15 évre növelte az elbirtoklási időt. ${ }^{14}$

A 2003-as Új Polgári Törvénykönyv Koncepciójában is helyet kapott a jogintézmény, akkor még apróbb eltéréssel. ${ }^{15}$

\section{Amerikai kitekintés: A Louisiana Civil Code elbirtoklásra vonatkozó szabályainak} hasonlatossága a jogcímes elbirtokláshoz

A magyartól eltérő, külföldi szabályozási modellek között nem egyben találunk olyan elbirtoklási formákat (Blanchette, www.lexology.com, 2017), ahol a jogcím - más formában bár, de - különös jelentőséggel bír. Tudvalevő, hogy az elbirtoklás megfeleltetése az angolszász jogban különösen problémás, a keresett jogintézmény esszenciája az elévülés keretén belül található meg igazán. A common law dogmatikájában ugyanis az idómúlás egyrészt messze nem élvez olyan kitüntetett szerepet, mint a civiljogi párjában, másrészt a jogvesztő határidő és az elévülési határidők közötti éles különbségtétel sem tehető meg. A civiljogi elbirtoklás fogalmához a common law fogalmai (pl. extinction, lapse, termination stb.) a prescription áll legközelebb (Barna, www.jogiforum.hu). Az Egyesült Államok jogrendszerében a

13 A Magyar Népköztársaság Polgári Törvénykönyve. Az. 1959. évi IV. törvény és a törvény javaslatának miniszteri indokolása. Közzéteszi az Igazságügyminisztérium, Budapest, Közgazdasági és Jogi Könyvkiadó, 1959. 100. p.

${ }^{14}$ A törvény indokolása a következőképpen fogalmazott: „Az ingatlanok elbirtoklási idejének felemelését indokolja továbbá az a körülmény is, hogy a Ptk már említett 1991-es módosításának eredményeként az állami tulajdonban lévő dolgokra korábban fennállott elbirtoklási tilalom megszűnése folytán az állami tulajdon is elbirtokolhatóvá vált. Az állammal szembeni elbirtoklás legkorábban 2001. június 9-én következhet be. Az 1991-98 közötti időszakban az állami vagyon teljes körű felleltározása megkezdődött ugyan, de az állammal szembeni elbirtoklás megszakadását eredményező intézkedések megtételére - számos esetben objektív okból - a szükséges mértékben nem kerülhetett sor. A Ptk. 1991-es módosítása óta eltelt idő a társadalmi tulajdon lebontásának körülményei között - az ingatlan-nyilvántartás közismert állapotára is figyelemmel - nem volt elegendő arra, hogy az állam tulajdonában maradó dolgok tulajdoni és használati viszonyainak rendezése teljes mértékben megvalósulhasson.” Forrás: 2001. évi XIX. törvény indokolása. (www.uj.jogtar.hu.) Letöltve: 2021. 07. 02.

15 4:56. \[A jogcímes elbirtoklás]

Az elbirtoklás öt év elteltével bekövetkezik akkor, ha a birtokos a dolog birtokát a tulajdonostól olyan szerződéssel szerezte, amelynek alapján a tulajdon feltétlen átruházását követelhetné, ha a szerződés az érvényességéhez megkívánt alakszerűségi követelményeknek megfelelne, és a birtokos az ellenszolgáltatást teljesítette. (Forrás: https://uj.jogtar.hu/\#doc/db/1/id/A0900120.TV/ts/fffffff4/ . Letöltve: 2020. november 30.) 
Debreceni Jogi Múhely 2020. (XVII.) 3-4.

Debreceni Egyetem, Állam- és Jogtudományi Kar, Debrecen

(University of Debrecen, Faculty of Law, Debrecen)

DOI 10.24169/DJM/2020/3-4/11

common law-t minden észszerűség ellenére sem sikerült leküzdenie a kodifikált jognak, azonban Louisiana Állam ebből a szempontból azonban különleges: a francia Code Civil mintájára 1808-ban a Louisiana Civil Code lett a magánjogi kódex, és az állam 1812-es föderációhoz történő csatlakozása után is hatályban maradt, mindmáig (Badó, 2012, p. 80). Louisianaban az ún „Ten-Year Acquisitive Prescription of Immovables" intézménye ${ }^{16}$ hivatott az elbirtoklást szolgálni. Eszerint, a birtokos 1$) 10$ év folyamatos birtoklással megszerzi az ingatlan tulajdonjogát akkor is, ha 2) annak birtokát nem a tulajdonostól szerezte, 3) rendelkezik azonban egy érvényes, jogátruházást célzó jogcímmel, és 4) birtoklásának tényében jóhiszemú. A jogintézmény célja elsődlegesen a múltbéli bizonytalanságok eloszlatása azzal, hogy a hosszas birtoklás tényével ne kelljen felesleges bonyodalmakba ütközni a tulajdonviszonyok vizsgálata kapcsán. Jelen dolgozatban kizárólag a jóhiszemúség és az érvényes jogcím vizsgálatára vállalkozom, a birtoklás fogalma mélyreható elemzésére itt most nincs lehetőség. ${ }^{17}$

A törvény a birtokló oldalán jóhiszemúséget kíván meg (West, 1979, La. Law Review, pp. 1022-1024), ami annyit tesz, hogy a személy valamilyen jogos és ésszerú oknál fogva úgy hiszi, ô a tulajdonos. Tévedése az eladó vonatkozásában releváns: azt hiszi, hogy az eladó is tulajdonos volt, és ebben alapos okkal bízik. Rosszhiszemú tehát, ha tudja, hogy az eladó nem volt tulajdonos, vagy tudja, hogy a jogcíme hibás. ${ }^{18} \mathrm{~A}$ törvény a birtokló javára vélelmet állít fel a jóhiszeműsége mellett. Ez a szemlélet tehát éppen ellentétes a magyar jogtörténetben megfogalmazódott felfogással, mely az elbirtoklásnál azért nem követel meg jóhiszeműséget az elbirtokló részéről, mert az elbirtoklást egyfajta magánjogi büntetésként kezelte a tulajdonossal szemben (Harmathy, 2014, p. 121).

A törvény a jogcímet - hasonlóan a Ptk.-hoz - a tulajdonátruházásra alkalmas, érvényes és jogos jogcímként határozza meg. ${ }^{19} \mathrm{Az}$ érvényes jogügylet körében a törvény a formai hibátlanságot és a pontos fogalmi meghatározást is megkívánja.

A jóhiszeműség és az érvényes jogcím közötti kölcsönös viszony nagy jelentőséghez jut az elbirtoklás kapcsán. Szemben a római joggal, ahol az érvényes jogcím a jóhiszemúség feltételeként, bizonyítékaként funkcionált (Duxbury, 2016, pp. 4-5), Louisiana állam Polgári Törvénykönyvében a kettô elválik egymástól. Elméletileg tehát előfordulhat, hogy a jogelőd semmis jogügylet folytán jutott az ingatlanhoz - tehát nem szerezhet még elbirtoklással sem tulajdont -, utódja -az elbirtokló- azonban érvényes jogcímmel szerezve, az előd tulajdonosi mivoltában jóhiszemúen bízva utóbb mégis tulajdonossá válhat. A jóhiszeműség tehát a birtokos személyében keresendő, de az jogügylet vizsgálata körében nem szempont.

\section{Konklúzió, lehetséges szabályozási irányok}

A fentieket összegezve felmerül a kérdés: mi lehetett a tényleges indoka ezen intézmény Polgári Törvénykönyvbe való beiktatásának, és maradéktalanul megfelel-e a tulajdonosi jogok védelmének, valamint az elbirtokló érdekeinek ez a szabályozási metódus? Amennyiben a második kérdésre nemleges választ adunk, úgy milyen eltérő megoldás létezhet?

A Polgári Törvénykönyv Kommentárja (Vékás-Gárdos, 2014) szerint a jogcímes elbirtoklás egyfelől kiváltani hivatott a tulajdonmegállapítási perek azon részét, melyet a Ptk. bíróság jognyilatkozat-pótló klauzulája ${ }^{20}$ alapján itélt volna meg. Ehhez kapcsolódik az elévülés általános, illetve a jogcímes elbirtokláshoz füzött határidők egybeesése is. Más álláspont szerint elsősorban nem forgalombiztonsági szempontot szolgál, hiszen nem a joglátszatban bízó felet védi (Pusztahelyi, 2014, p. 191) Konkrét

${ }^{16}$ LA. CIV. CODE: Arts. 3474, 3479-80,

${ }^{17}$ Készült: LEN KILGORE: The Ten-Year Acquisitive Prescription of Immovable. Louisiana Law Review

Volume 36 | Number 4. Summer 1976. 1000-1017. pp. Letöltve: 2020. november 29.

(https://digitalcommons.law.lsu.edu/lalrev/vol36/iss4/8)

${ }^{18}$ LA: CIV: CODE: Art. 1846

${ }^{19}$ LA. CIV. CODE: Art. 3483

${ }^{20}$ 6:184. \[Jognyilatkozat bírói ítélettel történő pótlása]

Ha a fél a szerzôdés alapján jognyilatkozat tételére köteles, és ezt a kötelezettségét nem teljesíti, a jognyilatkozatot a bíróság ítélettel pótolja. 
Debreceni Jogi Múhely 2020. (XVII.) 3-4.

Debreceni Egyetem, Állam- és Jogtudományi Kar, Debrecen

(University of Debrecen, Faculty of Law, Debrecen)

DOI 10.24169/DJM/2020/3-4/11

példaként nevesíthető esetek voltak, ha a földhivatal hiánypótlás nélkül utasította vissza, vagy ugyan kibocsátotta a hiánypótlást, de azt a felek - vagy azok jogi képviselői - nem teljesítették. ${ }^{21}$ Szintén előfordult, hogy a szerződést szárazbélyegzőjével ellátni hivatott ügyvéd meghalt, vagy nem praktizált tovább, esetleg ebbéli kötelezettségét elmulasztotta, az eladó pedig újabb adásvételi szerződést nem kívánt kötni. ${ }^{22}$ (A bíróság ilyenkor a vevő kötelmi hatályú jogcímére alapozva állapította meg a tulajdonszerzést.) (Tolnai-Fónyiné Kazareczki, 2020.) Az alaki hiba meglétének nem lehet feltétele a Földhivatal általi elutasítás, az azonban nem egyértelmú, hogy a puszta hanyagság folytán be sem nyújtott (alakilag hibátlan) szerződés megalapozhatja-e ezen kedvezményes elbirtoklást. (Tolnai-Kazareczki, 2020, p. 212.)

Egy interneten elérhető forrás ${ }^{23}$ a jogcímes elbirtoklás törvénybe iktatásában a „zsebszerződések” aranykorát látja eljönni: az eladók és vevők szerződéseiket saját maguk készítik el, ügyvédi vagy közjegyzői közremúködés nélkül. Végeredményben 5 éves cezúrával, bírósági határozattal megy foganatba a tulajdonszerzés. Vizsgálatra szorul, hogy esetleges közigazgatási költségek terén felmerül-e bármilyen kedvezmény az eredeti, és nem származékos tulajdonszerzés kapcsán. A válasz nemleges, ugyanis a feleknek változatlanul le kell róniuk az ingatlan-nyilvántartási bejegyzés után fizetendő illetéket, mivel az Inytv. ${ }^{24}$ 18. $\$$ (1) bekezdése, valamint az EBH2008. 1913 alapján az elbirtoklás visszterhes vagyonátruházási illeték alá tartozik.

A jövőben problémát jelenthet azonban az ingatlan-nyilvántartásban bízó, jóhiszemú szerzők védelmét ellátni hivatott általános szabály, illetve az ingatlanon fennálló jogok és követelések fennmaradása is. ${ }^{25}$ Világos, hogy ez a rendelkezés forgalombiztonsági, továbbá az állam múködésébe vetett általános állampolgári bizalom bástyájaként funkcionál, a törvény indokolása ezen felül hozzáteszi: „Az ingatlannyilvántartási szabályok körében elhelyezett általános rendelkezés az elbirtoklás körében is törekszik rászorítani az ingatlan elbirtoklóját arra, hogy tulajdonosi minőségének mielőbbi feltüntetését kérje, és ezáltal az ingatlan-nyilvántartási, valamint a tényleges állapot közötti eltérések lehetőségét csökkentse." (Kőváriné, 2019.) Véleményem szerint viszont a privilegizált elbirtoklók esetében más megközelítés is helytálló lehet. A törvény pontosan azon megfontolásból biztosítja a kedvezményes elbirtoklási időt, mert jogcímes elbirtoklás (nevéből is kivehetően) végső soron bár eredeti szerzésmód, de kapcsolata a származékos szerzésmódok releváns válfajaival tagadhatatlan (itt utalnék vissza a római jogi, továbbá a vizsgált francia-amerikai megközelítések igen szemléletes analógiájára).

A jogalkalmazásra hárul annak feladata, hogy feltérképezze a hatályos szabályok alkalmazhatóságának mértékét. De lege ferenda felmerülhet, hogy a jogcímes elbirtoklás tárgyi hatályát érdemes lenne kiterjeszteni az ingyenes szerződésekre, ahogy az is, hogy a privilegizált elbirtoklók ingatlan-nyilvántartáson kívüli tulajdonszerzésének jogi tényét kiemeljék az ingatlan-nyilvántartásban bízó, ellenérték fejében szerzőknek biztosított garanciális védelmi szabály alól, törvényi kivételt teremtve ezáltal.

Ha az elbirtoklót ex lege ellenszolgáltatásának megfizetése, és szakadatlan, sajátjakénti birtoklása okán, mindazonáltal a konstitutív bejegyzés elmaradásának ténye miatt 5 éves elbirtoklási idővel „kompenzáljuk”, abban az esetben de lege ferenda indokolt volna ezt a személyi kört kivonni az ingatlannyilvántartásban bízó szerzőkre vonatkozó generális védelmi rendelkezés alól. Értelemszerűen ezzel párhuzamosan a szabályozás egysége megbomlana, véleményem szerint azonban ez indokolt és arányos következménye a speciális szabályok meglétének. Itt különösen érdemes citálni Grosschmid lakonikusan precíz gondolatát: „... ne bizzál a telekkönyvben, hacsak azt tényleges birtoklás nem támogatja - ez a mi jogunk józan felfogása.” (Grosschmid, 1932, p. 403)

\footnotetext{
${ }^{21}$ (BH 2010. 06.)

${ }^{22}$ (BH 2007. 04.)

${ }^{23}$ KÖVÁRINÉ DR. BARTHA ÁgNES (2019) ZSEBSZERZŐDÉS KISKAPUJA AZ ÚJ PTK-BAN? In: Kislépték. hu. (Utolsó letöltés: 2020.12.01.) (https:// kisleptek.hu/hirek/ zsebszerzodes)

24 1990. évi XCIII. törvény az illetékekről

25 Ptk. 5:174. \ [Jóhiszeműen és ellenérték fejében szerzők védelme]

(1) A jóhiszemú és ellenérték fejében szerző javára az ingatlan-nyilvántartás tartalmát akkor is helyesnek és teljesnek kell tekinteni, ha az a valódi anyagi jogi jogállapottól eltér. Ennek alapján a szerző az e törvény szerinti védelemben részesül.
} 
Debreceni Jogi Mühely 2020. (XVII.) 3-4.

Debreceni Egyetem, Állam- és Jogtudományi Kar, Debrecen

(University of Debrecen, Faculty of Law, Debrecen)

DOI 10.24169/DJM/2020/3-4/11

Nehéz az elbirtoklás kapcsán frappáns befejező mondatot konstruálni. Pláne, ha a kutatási téma fiatal és kiforratlan. Öszintén remélem, hogy a munkámban felvázolt kérdések és válaszok felhasználhatók, hozzájárulva ezzel a civiljog magával ragadó szellemi folyójának sodrához, ugyanis sok örömömet leltem benne. Végül álljon itt García-Márquez. Száz év magány c. opusában kifejezett gondolata az alkotás kapcsán: „Még mielőtt elért volna az utolsó verssorhoz, már tudta, hogy soha többé nem lép ki ebből a szobából, mert úgy volt elrendelve, hogy a tükrök (vagy trükkök) városa szétszóródik a szélben és kihull az emberek emlékezetéből.” (Garcia-Márquez, 2012)

Irodalomjegyzék

A Magyar Népköztársaság Polgári Törvénykönyve. Az 1959. évi IV. törvény és a törvény javaslatának minisqteri indokolása (1959) Közzéteszi az Igazságügyminisztérium, Budapest, Közgazdasági és Jogi Könyvkiadó.

BADÓ ATTILA (szerk.) (2012) A jogrendszerek világa. Szeged, Pro Talentis Universitatis Alapítvány. 80. p. https://doi.org/10.26521/Profuturo/2012/1/5584

DR. BARNA ANDRÁS (www.jogiforum.hu) Hogy mondjuk angolul: elévülés, jogvesqtés Letöltve: https://www.jogiforum.hu/blog/5/56 (Utolsó letöltés: 2020. december 1.)

BLANCHETTE, NICOLAS (www.lexology.com) (2017) The Supreme Court confirms the broad principles of acquisitive prescription in real estate law.

Letöltve: $\quad$ https://s3.amazonaws.com/documents.lexology.com/4ba37e64-658f-4ec8-9807d28f5910c7c0.pdf?AWSAccessKeyId=AKIAVYILUYJ754JTDY6T\&Expires=1607182178\&Signature =yW4E6xh17bMOPE3Is\%2Fs1O8Lb0fM\%3D (Utolsó letöltés: 30. 11. 2020.)

Dr. BOÓc ÁdÁm (2009): A civilisqtika dogmatikája. Budapest, HVG-ORAC Kiadó Kft. 119. p. ISBN: 9789632580487

DUXBURY, NEIL (2016) Acquisitive prescription and fundamental rights. University of Toronto Press. 4-5. pp. University of Toronto Law Journal. ISSN 0042-0220 https://doi.org/10.3138/UTLJ.3873

GARCÍA-MÁrquEZ, GABriEL (2012) Száz év magány. Budapest, Magvető Kft.

GÁRDOS PÉTER (szerk.) (2009) Kézikönyv az Új Polgári Törvénykönyvböz: Budapest, Complex kiadó. ISBN: 9789632950488

GROSSCHMID BÉNI (1932) Fejez̧etek kötelmi jogunk köréböl. I. Budapest, Grill.

HARMATHY ATTILA (2014) Az elbirtoklásról. In: (L)EX CATHEDRA ET PRAXIS ÜNNEPI KÖTET LÁBADY TAMÁS 70. SZÜLÉTÉSNAPJA ALKALMÁBÓL. Budapest, Pázmány Press. ISBN 978963-308-207-2

HOMOKI NAGY MÁRIA (2001) A magyar magánjog történetének vázlata 1848-ig. Szeged, JATEPress. 48-49. pp.

JaSZENOviCSNÉ KósA CSILla (2012) Az elbirtoklás rejtelmei. In: Ügyvédek lapja: A Magyar Ügyvédi Kamara folyóirata, (51. évf.) 5. szám.

KILGORE, LEN (1976) The Ten-Year Acquisitive Prescription of Immovable. Louisiana Law Review Volume 36 | Number 4. 1000-1017. pp.

(Letöltve: https://digitalcommons.law.lsu.edu/lalrev/vol36/iss4/8) (Utolsó letöltés: 29.11.2020.)

KOlOSvÁry BÁlint (1942) A dologi általános tanai. In: SZLADITS KÁROLY: Magyar Magánjog V. Dologi jog. Budapest. Grill

KÖVÁRINÉ DR. BARTHA ÁGNES (2019) ZSEBSZERZŐDÉS KISKAPUJA AZ ÚJ PTK-BAN? In: Kislépték. hu. (Utolsó letöltés: 2020.12.01.) Letöltve: 2020. december 1. bttps:/ / kisleptek.hu/ hirek/ zsebszerzodes

LAMM VANDA (szerk.) (2018) Emberi Jogi Enciklopédia. Budapest. HVG-ORAC Kft. ISBN 
Debreceni Jogi Mühely 2020. (XVII.) 3-4.

Debreceni Egyetem, Állam- és Jogtudományi Kar, Debrecen

(University of Debrecen, Faculty of Law, Debrecen)

DOI 10.24169/DJM/2020/3-4/11

9789632583457

NAPÓLEON (2015) Az uralkodás müvészete. Helikon kiadó. ISBN 9789634795216

PUSZTAHELYI RÉKA (2014) Elévülés-Elbirtoklás-Telekkönyvi elbirtoklás. In: Miskolci doktoranduszok jogtudományi tanulmányai: Miskolci Egyetem Deák Ferenc Állam- és Jogtudományi Doktori Iskola kiadványsorozata. Miskolc. Bíbor Kiadó

ZIMMERMAN, REINHARD (2007) 'Extinctive' prescription under the Avant-projet. European Review of Private Law. 806-809. pp.

DR. SZŐKE IRÉN (2002) Az elbirtoklás, a használati jogokés a birtokvédelem birói gyakorlatának elemzése és annak tanulságai. Utolsó letöltés: 2020.12.01. letöltve: 2020. december 1. bttps://ptk2013.hu/polgari-jogikodifikacio/dr-szoke-iren-az-elbirtoklas-a-basznalati-jogok-es-a-birtokvedelem-biroi-gyakorlatanak-elemzese-es-annaktanulsagai-pjk-20023-3-18-o/595

TOLNAI IldiKÓ-FÓNYINÉ KAZARECZKI ANDREA (2020) Ingatlanjog I. Budapest. Wolters Kluwer Hungary Kft. Utolsó letöltés: 2020.11.30. Letöltve: 2020.11.30. https://mersq.hu/hivatkozas/m737YOVYYOV1809_88_p4\#m737YOVYYOV1809_88_p4

ISBN 9789632958989

TÓTH JUDIT (Szerk.) (2018): Alkotmányjog II. Alapjogok és emberi jogok. Szeged. Iurisperitus kiadó. ISBN 9786155411762

T/7971. számú törvényjavaslat a Polgári Törvénykönyvről. Előadó: Dr. Navracsics Tibor közigazgatási és igazságügyi miniszter. Budapest, 2012. július. Letöltve: (2020. november 29.) https:// www.parlament.hu/irom39/07971/07971.pdf

VÉKÁS LAJOS- GÁRDOS PÉTER (szerk.) (2018) Kommentár a Polgári Törvénykönyuröl szóló V. törvényhez: Wolters Kluwer Kft. Utolsó letöltés: 2020.11.30. Letöltve: (2020. november 30.) https:// uj.jogtar.hu/\#doc/db/367/id/A14Y1522.KK/ts/20200101/lr/chain14718/ ISBN 978963295733 3

VÉKÁS LAJOS (2019) Szerơơdési jog-általános rész: Budapest. ELTE Eötvös Kiadó. ISBN 978963312265 5

VÉKÁS LAJOS (szerk.) (2008) Szakértôi Javaslat az Új Polgári Törvénykönyv Tervezetéhez. Budapest. Complex Kiadó. ISBN 9789632249377

West, Paul Slocomb (1979) Ten Year Acquisitive Prescription: Good Faith and Interruption. 39 La. L. Rev. ZLINSZKY IMRE (1902) A magyar magánjog mai érvényben. Budapest. Franklin Társulat. 